\title{
New names in Veledella and Sastrapada. First description of male of Lamotteus ornatus Villiers (Reduviidae)'
}

\author{
Jenaro Maldonado Capriles ${ }^{2}$
}

\begin{abstract}
Veledella milleri Maldonado is a new name for $V$. variabilis Miller 1954, junior homonym of V. variabilis Miller 1953. Sastrapada hsiaoi Maldonado is a new name for $S$. robusta Hsiao 1973, junior homonym of S. robusta Villiers 1948. The male of Lamotfeus ornatus Villiers, 1947, is described.
\end{abstract}

\section{INTRODUCTION}

Recently I had the opportunity to study unidentified reduviids from the collection of Ohio State University (OSU). Among this material a male of Villiers' Lamotteus ornatus was found. It is deposited in OSU. Two homonyms were discovered in the literature search. New names are proposed below for these two cases. Dimensions in the descriptions that follow are in $\mathrm{mm}$.

\section{DISCUSSION \\ REDUVIIDAE \\ Harpactorinae \\ Veledella milleri Maldonado, new name}

Veledella variabilis Miller, 1953. Soc. Scient. Fenn. 13 (17):64. Male holotype, from the Philippines, in the British Museum (Natural History), senior homonym.

Veledella variabilis Miller, 1954. Treubia 22 (3):450. Male holotype, from Java, in Leiden Museum; junior homonym.

\section{Stenopodainae}

Sastrapada hsiaoi Maldonado, new name

Sastrapada robusta Villiers, 1948. Faune Empire fr. 9:376. Male holotype, from Gabon, in Museum National d'Histoire Naturelle, Paris. Senior homonym.

Sastrapada robusta, Hsiao, 1973. Acta Entomol. Sinica 20 (1):73.

${ }^{1}$ Manuscript submitted to the Editorial Board May 29, 1986.

${ }^{2}$ Ponce School of Medicine: Box 7004, Ponce, P. R. 00732 and Department of Plant Protection, Univ. P. R., Mayagüez, Puerto Rico 00708. The author is grateful to Dr. C. A. Triplehorn, OSU, Columbus, Ohio, for the loan of this material. 

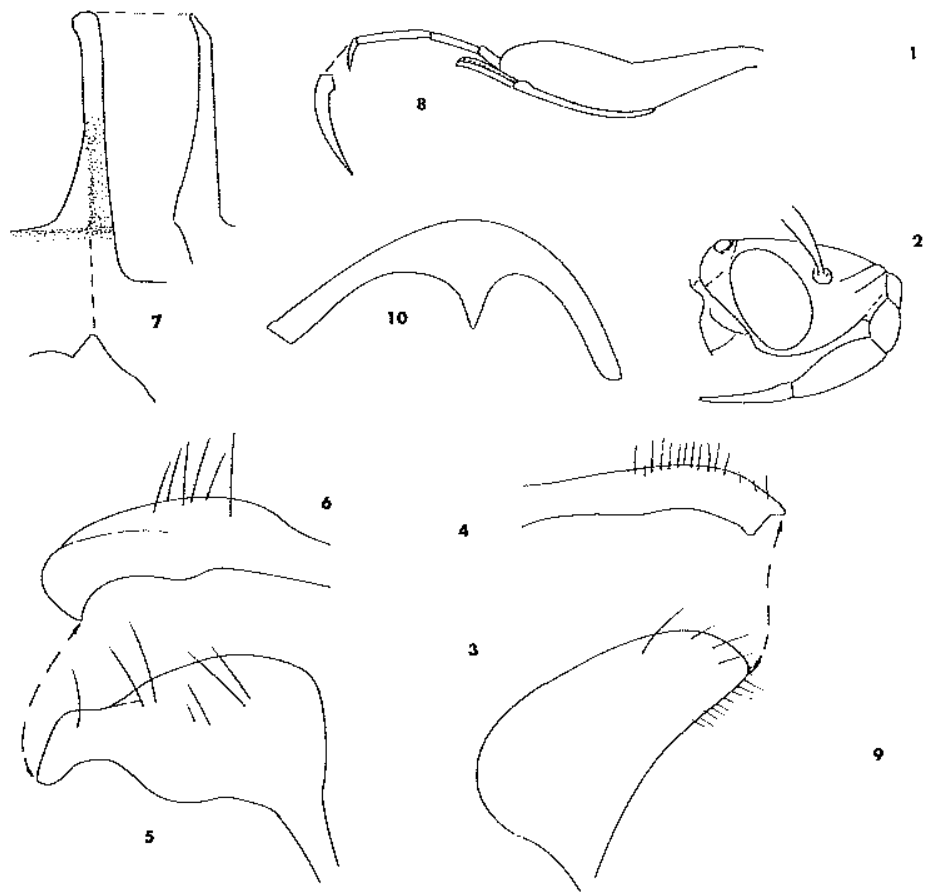

1

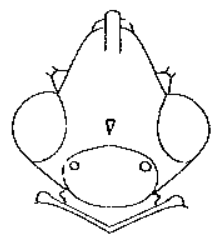

2

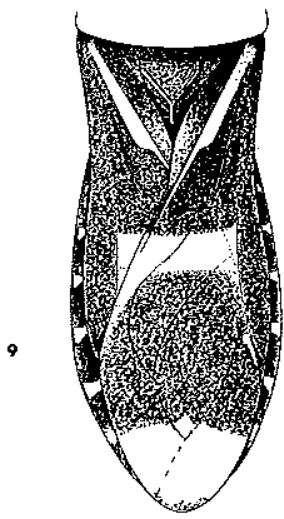

Plate I.-Lamotteus ornatus Villiers, male. 1. head, dorsal; 2. head, lateral; 3. left clasper, lateral; 4. Ieft clasper, dorsal; 5. right clasper, lateral; 6. right clasper, dorsal; 7 . hypopygial spine; 8 . protibia and tarsus lateral; 9 . habitus, partial dorsal view; 10 . seventh sternum.

Male holotype, from Kwantung, China, in Nankai University collection. Junior homonym.

\section{Peiratinae}

\section{Lamotteus ornatus Villiers}

Lamotteus ornatus Villiers, 1948. Faune Emp. fr. 9:253. Female holotype, from Guinea and Cameroon, in the collection of the Museum National d'Histoire Naturelle, Paris.

Male-mostly polished black (fig. 9); ornamented with yellowish white as follows: inner cell of corium, broad transverse band subbasally on membrane extending apicad, narrowly on inner margin of membrane; short longitudinal band adjacent to pterostigma; wider transverse band before apex of membrane; subtriangular small areas basally on each connexival segment, upper margin of trochanter, middle of femur basally on anterior surface. Last segment of rostrum apically brown. Outer cell of hemelytra dark gray; inner area of clavus both sides of apex of scutellum light grayish brown. 
Head as in figures 1 and 2 ; length 1.8 , width across eyes 1.52 , interocular space 0.7 , interocular suture before apex of inner margin of eyes, from interocular suture to apex of head 2.1, from same to base of head 1.2, preocular length 0.7 , postocular length 0.4 ; ocelli slightly above surface of cranium; collum produced laterally. Antenna: I, 0.8; II, 1.7; III, 2.3: IV, 0.7; first the thickest, twice as thick as third, segments 1-4 successively thinner, very fine and short pilose, 2 or 3 long fine setae on all segments. Beak: I, 0.9; II, 1.5; III, 1.5. Collar thin, angularly concave, lateral angles round; anterior and posterior lobes with normal, shallow constriction between them; anterior lobe length 1.7, greatest width 2.25 , median sulcus on basal half; $3+3$ sulci each side of median line, poorly defined, made by shallow mostly transverse striations, lateral margin finely carinate; posterior lobe length 1.05 , width 3.3 , anteriorly with very short prolongation of median sulcus of anterior lobe, anterior marginal area crenulate, crenulations extending as irregular corrugations to midlength of lobe, thence smooth to apex. Metapleura granulose, bicarinate above. Legs unspined; procoxal length on anterior face 1.2; profemur greatly thickened, nearly half as wide as long (1.0 x 2.3); mesofemur thinner than profemur, thickest after midlength, $2.3 \times 0.6$; metafemur $3.4 \times 0.5$; protibia (fig. 8 ) with apical half angularly bent upward, flattened dorsoventrally; spongy fossa wide, flattened, reaching $2 / 3$ of segment and surpassing apex of segment; tarsal segments: I, 0.2; II, 0.3; III, 0.5; claws thickened basally. Mesotibia cylindrical, straight, spongy fossa reaching apical third of segment. Metatibia cylindrical, without fossa, thickly setose apically; tarsus I, 0.25 ; II, 0.5 ; III, 0.7 . Legs with moderately abundant short, semidecumbent pilosity and, except protibia, with moderately abundant long fine setae, setae as long or $2 \mathrm{X}$ or $3 \mathrm{X}$ as long as diameter of segment. Prosternum mostly in front of procoxae, its caudal apex slightly surpassing anterior margins of coxae.

Genitalia as in figures 3 to 7; seventh sternum biconcave (fig. 10).

Africa, CAMEROON, Center-South Prov., Yoounde,Congo-Guinea Rain Forest, ix-30 to $\mathrm{x}-4-1980$, elevation $700 \mathrm{~m}$., black light, at OSU.

Lamotteus is characterized by a slightly bent and partially flattened protibia, a moderate constriction between the two pronotal lobes, flat and broad spongy fossa on the ventral face of the protibia, fossa reaching past midlength in the female and $2 / 3$ in the male, the preocular part of the head as long or slightly shorter than postocular, profemur very thick. The male fits without difficulty in Villiers' (1948) key to genera. The genus is monotypic.

\section{RESUMEN}

\section{Descripción del macho de Lamotteus ornatus}

El género Lamotteus se caracteriza por tener la protibia parcialmente achatada y ligeramente doblada, leve constricción entre los lóbulos del 
pronoto, fosa esponjosa ancha y achatada en la faz ventral de la protibia, la fosa alcanza la mitad de la protibia en la hembra y 2/3 en el macho, la región preocular de la cabeza es tan larga o un poco más larga que la postocular. El macho se puede identificar sin dificultad en la clave genérica de Villiers (1948). El género es monotípico. 